\title{
It's Only Teenage Wasteland: The Home Media Revival of Freaks and Geeks
}

Katie Barnett

\section{Introduction}

For eighteen episodes, Freaks and Geeks (NBC, 1999-2000), a high school comedy-drama set in the early 1980s, cast its focus back in time to construct a realistic, often bleakly funny image of teenage life. Yet despite its cultural backdrop of Dallas, Led Zeppelin and Atari video games, in one significant way, Freaks and Geeks was ahead of its time. Cancelled after the production of these eighteen episodes, only twelve of which were originally aired, the programme's televisual legacy would come to be represented by the online fan campaign that ensured, first, the broadcast of the missing episodes and, second, the eventual —if delayedrelease of the series on DVD.

This chapter will explore the circumstances surrounding the cancellation of Freaks and Geeks and its status as a cult programme, a label that is in part linked to the programme's struggle to be broadcast and then released. It will consider one of the main barriers to its home media release, the licensing of the vast amount of music used in the programme, and how crucial the music is to its construction, both aurally and narratively. It will also examine how Freaks and Geeks offers audiences a glimpse 'back in time' to before the majority of its stars were famous, a time capsule of talent that would fully emerge during the 2000s.

After the fact, Freaks and Geeks is a regular feature on lists of critically-acclaimed television. Time counts it as one of its All-Time 100 TV Shows. (Time, 2007) 16 years after its cancellation, Rolling Stone's list of 100 Greatest TV Shows places it at number 11, ahead of shows including Games of Thrones (12), The West Wing (16), Twin Peaks (17), Deadwood (23) and Buffy the Vampire Slayer (38), noting that although "it tragically lasted only one season... all 18 episodes hit home". (Sheffield, 2016) It is regularly listed amongst the 
television programmes that were cancelled too soon. (Jackson, 2009) However, despite these numerous critical accolades, a 2000 Emmy win (for Outstanding Casting for a Comedy Series), and a small but dedicated fanbase, Freaks and Geeks would largely disappear between the end of its original broadcast in 2000 and its eventual DVD release in 2004, via the newlyestablished Shout! Factory. What follows is an exploration of Freaks and Geeks' rising cult status and the relationship between this and its home media reincarnation.

\section{Where were they then? A time capsule of future stars}

Freaks and Geeks' cult status can be attributed in part to its ephemerality and in part to the audience pleasures it inspires, both of which are discussed below. It can also be linked to the notion of authorship surrounding its conception and creation, and the fact that many of its young cast became stars in the years that followed.

Teen dramas have not often been characterised by a high level of authorship, perhaps lacking the requisite prestige. Yet in the late 1990s, this began to change. Matt Hills suggests that Dawson's Creek made a conscious attempt to mark itself out as a piece of quality television - as opposed to the less prestigious label of 'teen TV' — in part by emphasising the role of its creator Kevin Williamson. (2004: 54) Williamson originally came to prominence as the screenwriter of successful teen slasher films Scream, Scream 2 (Craven, 1996; 1997), and I Know What You Did Last Summer (Gillespie, 1997), before going on to create Dawson's Creek for The WB, placing him firmly in the centre of what Clare Birchall calls the "teen-pic" revival of the 1990s. (2004: 177) The opening credits of Dawson's Creek conclude with the words “created by Kevin Williamson", over an image of its main cast. Williamson's name, above all, is given prominence. As Hills states:

It is Williamson's construction and mediation as a TV auteur, also buttressed and sustained by his extremely successful work in teen 
horror cinema, that extends the status of 'authored' quality teen

TV to Dawson's Creek. (2004: 59)

A year later, Freaks and Geeks would feature creator Paul Feig and executive producer Judd Apatow's names prominently in its own opening credits. The desire for an "author" to attach to the series may be read, in the same way, as an attempt to grant the series a weight not often offered to teen programming. This goes hand in hand with the "textual sophistication" that Hills marks out as a feature of Dawson's Creek and which, equally, may be applied to Freaks and Geeks. (2004: 56) The difference here is that Feig and Apatow's profiles would largely rise after Freaks and Geeks, much like the "author" of Buffy, Joss Whedon, whose own cult status largely derives from his re-imagining of the teenage vampire slayer.

Freaks and Geeks, then, benefits from having two clearly defined "authors". For audiences, it also acts as a televisual time capsule, a handy 'where were they then?' guide to its stars and creators. After the programme's cancellation, Apatow's Hollywood film career developed rapidly. The 40 Year Old Virgin (2005) and Knocked Up (2007) both saw Apatow garner success as director and co-writer; as producer, his name became synonymous with a number of successful films of the next two decades, including Anchorman (McKay, 2004), Superbad (Mottola, 2007) and Get Him to the Greek (Stoller, 2010), on all of which he acted as producer. Apatow also produced Bridesmaids (2011), directed by Feig, whose own postFreaks work includes directing episodes of Arrested Development and The Office, as well as The Heat (2013), Spy (2015) and Ghostbusters (2016).

Though Apatow's involvement with Freaks and Geeks is far from his first, or only, work in television, it acts as a marker on his rise to filmmaking prominence. It also marks his first collaboration with Seth Rogen (who plays Ken) and Jason Segel (Nick), both of whom would work with Apatow on numerous future occasions. Segel's collaborations with Apatow include Knocked Up, Forgetting Sarah Marshall (Stoller, 2008) and This is 40 (Apatow, 2012), 
while Rogen has starred in, amongst others, The 40 Year Old Virgin, Superbad and Knocked $U p$, and acted as producer alongside Apatow on films including Pineapple Express (Green, 2008) and Funny People (Apatow, 2009). Freaks and Geeks, then, acts as a precursor to these collaborations, and for fans of Apatow's work offers a glimpse of the beginnings of these creative relationships.

If part of Freaks and Geeks' perceived quality lies in its personnel behind the screen, there is - as the subsequent career trajectories of Rogen and Segel indicate - an equal claim in front of the camera. Fellow 'freak' James Franco (Daniel) is perhaps the series' other breakout success story. Franco worked with Apatow and Rogen on Pineapple Express and has frequently acted in projects for Rogen and Rogen's creative partner Evan Goldberg, including This is the End (2013), The Interview (2014), and 2016's Sausage Party (Vernon and Tiernan), for which Rogen and Goldberg wrote the screenplay. His work on films including 127 Hours (Boyle, 2010), Milk (van Sant, 2008), Rise of the Planet of the Apes (Wyatt, 2011) and Sam Raimi's Spider-Man trilogy (2002; 2004; 2007) had solidified his Hollywood success.

As well as offering a glimpse of its stars before many of them achieved mainstream fame, Freaks and Geeks also rewards audiences with numerous guest appearances and cameos. At the time, many of these guest stars were at the beginning of their careers; it is only now, on DVD, that fans are provided with the opportunity to 'star spot' as they watch the show. These stars include Ben Foster (Eli), Shia LaBeouf (Herbert), Rashida Jones (Karen Scarfolli), David Krumholtz (Barry Schweiber) and Lizzy Caplan, in her first professional role as Sara. Although there are exceptions - Ben Stiller, for example, appears as a Secret Service agent in "The Little Things", and Tom Wilson, best known as Biff from the Back to the Future franchise, is a recurring cast member - these guest appearances tend only to be significant after the fact, eliciting the pleasure of recognition in audiences who revisit the show through home media. Freaks and Geeks' cult status, then, is only enhanced over time. 


\section{The cult of cancellation}

The roots of this cult status can be traced back to the programme's cancellation in 2000. In being cancelled, Freaks and Geeks joins the echelon of programmes with similar fates for which fans have, in many cases, campaigned vociferously to see return to the air. Sometimes, audience activity has been sufficient in convincing networks to reverse a decision, such as Fox's revival of cult animated comedy Family Guy (1999-2002; 2005-present) after significant DVD sales indicated an enduring audience remained. In other cases, fan contact with networks has been a method of attempting to save cult favourites. Fans' letter-writing campaign to the producers of the original series of Star Trek, cancelled after three seasons in 1969, is an early example of audiences pressuring a network (NBC) to revive a programme. (Pearson, 2010) This model of direct pressure has endured. Fans wrote letters in attempts to reverse the cancellation of Cagney and Lacey (CBS, 1982-88) and Twin Peaks (ABC, 1990-91), the former campaign securing Cagney and Lacey's survival and the latter convincing ABC to air the remaining episodes of Twin Peaks.

My So-Called Life (ABC, 1994-5), is another prominent example of a show that was critically acclaimed and yet remained unrecognised by executives. (Davis and Dickinson, 2004: 8) After ABC cancelled the show after one season, fans launched an online campaign to have it brought back for a second. This marked the first time fans had organised online to attempt to influence a network and revive a beloved show, and the model would become more familiar over the next decade. After the ultimately unsuccessful campaign to bring back My So-Called Life, similar campaigns — often creative and sophisticated — targeted other programmes such as Roswell (The WB/UPN, 1999-2002), Firefly (Fox, 2002), Veronica Mars (UPN/The CW, 2004-2007) and Chuck (NBC, 2007-2012). While some of these were successful (to varying degrees), others - including the campaign surrounding Freaks and Geeks-were not. Due to 
their early cancellation and subsequent delay in being made available on DVD, Glyn Davis and Kay Dickinson label shows such as Freaks and Geeks and My So-Called Life as "prematurely lost texts". (2004: 8) In part, this label contributes to their cult status. The fan activity around these cancelled — or threatened — shows highlights the centrality of the audience in defining a series as "cult".

The importance of the viewer to the label "cult" has been discussed by numerous scholars. Roberta Pearson suggests, for example, that the "common characteristic [of cult television] is found not in the texts, but in their viewers". (2003: online) Specifically, for Gwenllian-Jones and Pearson, cult programmes encourage and reward "close textual analysis, interpretation, and inventive reformulations" by an audience. (2004: xii-xvi) This shift in definition mirrors the growing generic diversity of cult television, expanding as it has from primarily fantasy, science fiction and horror programmes to a broader range of genres. It is the intense involvement of viewers in the televisual text that often inspires the cult label. As Stacey Abbott observes, "[c]ult television persists because the creators and the fans keep fighting for their little, original, often challenging shows." (2010: 3)

Jes Battis suggests that there are two ways in which a programme becomes cult. One way relies on a programme that is seen to be transgressive and therefore of limited appeal becoming an unexpected success, embraced by its audience and often garnering critical acclaim. The second way sees cult status conferred once a programme has been "cancelled, forgotten, and then resurrected by fan intensity". (2010: 78) Freaks and Geeks would appear to be an almost perfect example of the latter. Its cult status, at least in part, resides not simply in its textual content, but in its cancellation and subsequent, belated resurrection. Although its focus - the marginal, troubled teenagers who populate William McKinley High in the 1980-1 school year - has some obvious cult appeal, the abrupt cancellation, the ensuing fan campaign, 
and Shout! Factory's enthusiastic adoption of the programme in 2004, are equally responsible for the show's cult status.

Implicit in the cancellation of Freaks and Geeks and the fans' attempts to revive it is an assumption of unfairness, of a show condemned before its true potential could be understood. Davis and Dickinson suggest that "there are some programmes which seem to have accrued the status of 'quality' due to having being cancelled”, and certainly Freaks and Geeks' cult status has only increased in the years following its cancellation; the period of unavailability before the DVD release further fuelled such status. (2004: 8) That is not to say that its cult or 'quality' status is unearned. Rather, as I will discuss below, there is a depth and authenticity to the show that lends itself to repeated viewings and immersion, which is facilitated by being available on DVD.

\section{DVD release}

Four years passed between the end of the original broadcast of Freaks and Geeks and it being made available as a DVD box set. During this period, fans launched Operation Haverchuck, coordinating online to raise money to place ads in industry publications such as Variety, and bombarding other networks with correspondence and peanuts (a reference to the character Bill Haverchuck's severe peanut allergy) to draw attention to the size and dedication of the show's fanbase. (Dehnart, 2000) When this ultimately failed, another challenge presented itself: how to secure the home media release of Freaks and Geeks.

Davis and Dickinson suggest that, though teen television may be built upon "delicate foundations", the proliferation of home media formats and the increasing availability of these programmes on DVD (and earlier, video) can fortify their status. (2004: 4-5) Indeed, Birchall suggests that the rise of home media, and the concomitant possibility of repeat viewings, is integral to the revival of teen programming in the 1990s and beyond. (2004: 177) The label of 
"prematurely lost text", then, is complicated by the possibility-indeed, now almost inevitability—of a DVD release. Freaks and Geeks primary designation as a teen drama is also important to consider here. Davis and Dickinson argue that the makers of teen-oriented programmes have wilfully exploited their fan audiences through the production of "extratextual manifestations"-including DVDs, soundtrack CDs, and novelisations, to name the most common - to be consumed by a teen and young adult audience already primed for capitalist consumption. (2004: 8) The relative unavailability of any such extra-textual manifestation in the case of Freaks and Geeks may be understood, therefore, as particularly frustrating for an audience increasingly accustomed to a home media landscape characterised by availability.

It was the establishment of the distribution company Shout! Factory in 2003 that finally set the wheels in motion for Freaks and Geeks. Shout! Factory was set up by Garson and Richard Foos and their business partner Bob Emmer, all three of whom had previously been involved in Rhino Entertainment, co-founded by Richard Foos in 1978. In 1985 Rhino launched Rhino Home Video, focusing on classic television series and cult films, a precursor to what the Foos and Emmer would go on to do with Shout! This background in the music industry informed Shout!'s initial focus on music-oriented releases (both CDs and DVDs); their championing of Freaks and Geeks is significant insofar that music plays a central role in the programme, as discussed below.

Freaks and Geeks was Shout!'s first DVD release of a television series. Because of the considerable cost of releasing Freaks and Geeks with its original soundtrack intact, the home media release was built upon the pledge of fans to purchase the series should it be made available. As noted above, Family Guy was reinstated on Fox after impressive DVD sales, and Futurama (Fox, 1999-2003; Comedy Central, 2010-13) made a comeback via Comedy Central after strong sales of its straight-to-DVD films in 2009. Other shows, such as Veronica Mars, 
have benefitted from Kickstarter campaigns that see fans pledge money to, in this case, fund a feature-length film to wrap up the series. This financial investment on the part of fans offers an incentive to a network or distribution company, guaranteeing both interest and return on their commitment to a show.

In return for the fans' pledge to buy the DVD, Shout! produced a box set that included numerous extras, including bloopers, deleted scenes, behind the scenes footage, and multiple commentaries on each episode. The addition of these extras heighten the feeling of proximity fans could achieve. Given the DVD collection's delayed release and the difficulty in accessing episodes of Freaks and Geeks after its broadcast, there is sense of rewarding fans for their wait by providing extra insights and content. In ensuring that not just the episodes, but the auxiliary features, were released, Shout! enabled fans to rediscover their appreciation for the programme, as well as attract a new generation of fans, many of whom would welcome the retrospective opportunity to see Freaks and Geeks' stars 'before' they were famous.

\section{Musical heritage}

As noted above, one of the main barriers to the DVD release was the cost of licensing the soundtrack and obtaining the rights to the music used within the programme. As such, Freaks and Geeks' relationship to music is worth exploring at some length here. As Rhonda V. Wilcox notes, "[m] usic and sound have been too often omitted from serious aesthetic discussions of television." (2010: 32) In Freaks and Geeks, however, music plays a central role. In this section, I will discuss how the music contributes to the aesthetic and narrative of the programme, and why it was so crucial that the original soundtrack be retained for home media release.

Television soundtrack albums have often been released an auxiliary products, to accompany programmes from Ally McBeal to Doctor Who, Cold Feet to Sons of Anarchy. 
Amongst the teen shows mentioned above, Buffy the Vampire Slayer and Dawson's Creek are both notable for releasing multiple soundtracks, featuring selections of music from the show. This is, of course, another reminder of the link between cult programming and consumer habits, and of the ways in which teen audiences in particular have been encouraged to consume such auxiliary products.

What is interesting in the case of Freaks and Geeks specifically is the fact that the music at its centre is not contemporary. Rather than exposing its younger audience to current artists whose appearance on the programme may function as secondary marketing (see, for example, Valerie Wee's discussion of the Sabrina the Teenage Witch/Britney Spears crossover for a successful mainstream occurrence of this phenomenon), or whose inclusion on the soundtrack may boost an affiliated record company's sales (Dickinson, 2004), Freaks and Geeks features bands and artists that a younger audience may find in their parents' own record collections.

The importance of music in cult television is noted by Janet K. Halfyard, who suggests that "the musical strategies that it [cult TV] employs... set it apart in some areas." (2010: 121) In Freaks and Geeks, music functions to root the programme in its particular space and time; as such, it provides the indelible backdrop to the series. The theme song, perhaps inevitably, is Joan Jett's “Bad Reputation". Jett's 1980 song not only serves as a temporal marker, but encapsulates the attitude of the freaks at the programme's centre. Wilcox notes that a cult programme's theme song is significant "because it is the doorway through which we enter the special world of the cult show." (2010: 32) In line with this, Halfyard suggests that "the theme tune... is a fixed point that is central to the creation of a series identity". "Bad Reputation" sets up the defiant tone of the series, which sees its characters, at various points, railing against authority and expectation. In opening with this track, over images of the main characters having less-than-flattering school photos taken, Freaks and Geeks immediately establishes its ground. Its focus is firmly set on those at the margins. 
More broadly, the programme's soundtrack features Van Halen, Cream, Styx, Deep Purple, Journey, Ted Nugent, The Who, The Grateful Dead, Bob Seger, Joe Jackson and Billy Joel, amongst many others. As with the theme song, much of the music used in Freaks and Geeks was released between 1977 and 1980, mirroring the setting. Teen programming of the 1990s and 2000s often uses popular music from the 1970s and 1980s, which leads Dickinson to suggest that this is a symptom of nostalgia on the part of the programme makers, a reflection of their youth rather than that of the presumed audience. (2004: 106) Because of its dislocated temporality, however, in Freaks and Geeks the same music does not function as nostalgia. Rather, the music works to root its characters in the immediate and emerging popular culture of their time. When, for example, Sam (John Francis Daley) and Cindy (Natasha Melnick) dance to Styx's "Come Sail Away" at the school dance at the end of the first episode ("Pilot"), they are dancing to a relatively recent (1977) Billboard hit, not a nostalgic sound of the past.

The freaks, in particular, are voracious consumers and critics of contemporary music. Nick is an aspiring drummer and viewers are introduced to his character as he makes the following proclamation: "Hey, I believe in God, man. I've seen him, I've felt his power! He plays drums for Led Zeppelin and his name is John Bonham, baby!" ("Pilot") In the second episode, "Beers and Weirs", Nick is devastated at the news of Bonham's death. He frequently extols the virtues of Rush's Neil Peart ("the greatest drummer alive!"), further fuelling his desire to be a drummer. As a group, the freaks share a love for Cream and Led Zeppelin. Music, then, becomes a kind of currency. It is used by Lindsay (Linda Cardellini) in her attempts to prove to the other freaks that she is one of them. In "I'm With the Band", she pushes Nick to take his music more seriously, irritating the other members of his band in the process. When challenged by Ken, Lindsay snaps: "God, how could I be so awful to actually suggest that you play an entire song correctly all the way through! God knows Zeppelin only play half of 'Stairway to Heaven', and The Who never even practices 'Teenage Wasteland'." Ken's 
response is part exasperation, part smugness. "“Baba O'Riley'," he corrects her. "The name of the song is 'Baba O'Riley'. It's on Who's Next?" In this moment, Lindsay's misstep is revealing. Ken's suspicion that Lindsay is not quite authentic is confirmed in her less-thanencyclopaedic knowledge of The Who's back catalogue.

Music continues to shape Lindsay's relationship with the freaks, and in the final episode of the series, it becomes the catalyst for her decision to ditch summer school in favour of following The Grateful Dead around the country. It is used by Nick to try and transcend his army-bound, suburban experience, and by Daniel—equally unsuccessfully— to impress a punk girl in "Noshing and Moshing". Music also augments the generational difference between children and parents, a reality that is frequently referenced. Lindsay and Sam's father, Harold Weir (Joe Flaherty), is particularly disillusioned with modern music:

Harold: I guess you'd prefer we listen to that punk rock music I've been reading about. You know those Sex Pistols? They spit on their audience! Yep, that's what I wanna do. Spend my hard earned money to be spit on. Now that's entertainment. [...] Elvis didn't expectorate on his fans.

Later, Harold promises Lindsay she can attend The Who's concert, but only once he has listened to the record in question: "I'll be listening to it backwards, too!" He is equally disparaging of Neil Peart's drumming, convincing Nick to listen to Gene Krupa for comparison. Nick's dad, meanwhile, is derisive of his son's musical ambitions and seeks to quash them by selling Nick's drum kit.

Music also influences the paraphernalia of the show, from the Journey poster on Lindsay's bedroom wall to the band t-shirts worn by Nick, Ken and Daniel. When faced with a math problem he cannot complete (an admission that will prove he has previously cheated), Daniel etches ZEPPELIN ROCKS into his paper, in lieu of the algebraic answer. Yet beyond 
this, the actual music is integral to the show's soundtrack. It is here that the programme's relationship to its musical backdrop became problematic for any potential distributors, for whom altering the music would impact on the fabric of the programme itself.

Each episode is built around a number of rock or pop tracks. As Dickinson notes, "[u]nlike... the specially composed score, the songs we hear on teen TV shows have usually held a prior place in the world and have already established a set of definitions for themselves." (Dickinson, 2004: 100) Freaks and Geeks employs a variety of contemporary songs in order to root itself in its early 1980s setting. Beyond this, the songs contribute to the narrative, notably in the opening scene of the first episode. In this scene, the show sets out its stall by panning beyond the earnest conversation between a cheerleader and her jock boyfriend to its ultimate subjects: the freaks, under the bleachers, and the geeks. As the camera reaches the freaks, Van Halen's "Runnin' with the Devil" (1978) can be heard. When the camera pans away to the geeks, the soundtrack replaces Van Halen with Kenny Loggins' "I'm Alright”, from the 1980 Caddyshack soundtrack. As well as anchoring the episode to a particular time, the latter track highlights the geeks' penchant for farcical comedy (their love of Bill Murray is perhaps only surpassed by their obsession with Steve Martin), and the accompanying uncool factor, as they delightedly act out a scene from the film. The freaks, meanwhile, are marked out by the sound of rebellious hard rock, the aural accompaniment to their disaffected lounging beneath the bleachers.

In 2000, Fox Family picked up the previously unaired episodes of Freaks and Geeks for broadcast, with one notable change: much of its soundtrack was replaced, such was the cost of bringing the show to air with its original soundtrack intact. This allowed audiences to see the entirety of the first series for the first time; the music, in this instance, becomes a secondary concern. And yet the aural backdrop of Freaks and Geeks is not merely incidental. It is integral to the historicity, characterisation, and tone of the programme. The resistance to releasing 
Freaks and Geeks without its original soundtrack points to the importance of music to the series; the fact that Shout!, with its founders' credentials in music distribution, chose it as their first home media release further underlines the importance of its soundtrack as a crucial element of the audience's experience.

\section{Authenticity and repeat viewing}

Sam's crush on his classmate Cindy is one of the series-long arcs established in Freaks and Geeks' run. In the pilot episode, Sam wonders aloud to his friends whether he might ever have a chance with Cindy. Neal (Samm Levine) incisively sums up Sam's chances: "She's a cheerleader. You've seen Star Wars 27 times. You do the math."

In 1980, the year Freaks and Geeks begins, U.S households with a VCR amounted to only two per cent. (Ornstein, 2015: 199) The Weirs, like most families, own a TV but not a VCR. Home media has not permeated the landscape of Freaks and Geeks. A decade later, two thirds of households would have a video recorder, following a home media boom in the midto late-1980s. (Bierbaum, 1990: 31-2) In Sam's world, then, to see Star Wars 27 times would involve 27 trips to a movie theatre. This pre-video culture is underlined by scenes in the episode "The Little Things" when he takes Cindy to see The Jerk, a film that he evidently knows well; in the previous episode, "Smooching and Mooching", he has already declared to his friends that "The Jerk is the perfect movie", suggesting that he has seen it in theatres at least once before.

Sam's own media consumption is testament to the appeal of repeatability, even in an age where to miss a broadcast of Dallas (a perennial concern of Bill's [Martin Starr]) is to have no expectation of catching that episode in the near future. Barbara Klinger suggests that "[r]epetition... is a cornerstone of the consumer's experience of entertainment that has the potential to be as enjoyable as it is inescapable." (2006: 136) There is pleasure, for Sam, in the 
familiarity of The Jerk, and consternation at Cindy's response: "Cindy and me went to see The Jerk and she didn't laugh once!" he reports back to Lindsay. Sam is a fan in the way that a part of Freaks and Geeks' audience are fans. His love for Star Wars transcends simply seeing the film 27 times. He has a Star Wars bath towel, Star Wars sheets, and Star Wars notepaper. The inside of his locker is covered with pictures of Darth Vader. Beyond these commitments to the Star Wars marketing machine, Sam, Neal and Bill are often seen quoting or acting out scenes from their favourite films. In Sam and his friends, Freaks and Geeks reflects fandom and these pleasures of familiarity and repeatability back at its audience, many of whom would come to the series following its DVD (and later, Amazon and Netflix) release.

Although, as Davis and Dickinson suggest, some television programmes popular with teen audiences may not be made with longevity in mind, Freaks and Geeks bears up under repeat viewings. Indeed, there are numerous factors that encourage an audience to take pleasure in watching the episodes more than once. As discussed previously, the opportunity to 'star spot' is one such factor. There is also the programme's commitment to its own internal temporality, which rewards fans in small but significant ways. In "Smooching and Mooching", for instance, Sam debates what to wear to a party. He pulls various items from his closet, including the illadvised powder blue jumpsuit that he bought, memorably, in "Looks and Books". Likewise, the programme is aware of its external temporality, as when Nick mourns John Bonham in the second episode, which takes place early in the school year, mirroring Bonham's death in September 1980.

Essentially, it is authenticity that gives Freaks and Geeks its texture; in turn, it is this authenticity that rewards fan audiences who may view episodes multiple times. Although there are only eighteen episodes, they tend to be dense with background information and parallels. The "immersion" offered by home media allows for an appreciation of these small moments. (Klinger, 2006: 136) For example, in the second episode, "Beers and Weirs", Sam finds himself 
sitting beside Ken at the party. Sam is having a terrible time due to his fear that Lindsay's friends will trash the house while their parents are away; Ken is having an equally bad time because the beer has been switched out for a non-alcoholic variety by Sam, Neal and Bill. Sam asks if Ken and his friends can “make sure [my sister] doesn't get in too much trouble?" Ken agrees: "Sure. Which one's your sister?" To Ken, Sam—geek, freshman, stranger—is barely worth acknowledging. In the penultimate episode, "The Little Things", Sam and Ken meet again in the school bathroom. Sam is preparing to break up with Cindy, while Ken is agonising over whether to break up with his own girlfriend over her admission that she was born intersex. "You're Lindsay's brother, right?" Ken asks. He responds: "Sam, yeah." The two share a moment of bonding over their respective problems. While Sam laments the fact that he and Cindy "never have any fun together", Ken responds by reflecting, "my girlfriend's pretty cool when it comes to stuff like that". "God, then what's the problem?!" demands Sam. Sam and Ken rarely cross paths in the series, yet these two exchanges almost bookend the programme's run. Fans will note the parallels between these two scenes (and the fact that Ken still does not remember Sam's name), but also the subtle shifts. At some point during the school year, Ken has become sufficiently aware of Sam (and, by implication, less hostile towards Lindsay) to speak directly to him. Sam, too, replaces the awkwardness from episode 2 with something approaching aggravation in episode 17, aimed at Ken's failure to recognise his girlfriend's appeal.

There is also pleasure, perhaps, in speculating what happens between the episodes. Nick, for instance, goes from a stoner who is the first to declare that "disco sucks" in the first episode, to a guy who has given up weed and taken up disco dancing in the final episode ("Discos and Dragons"). This transformation largely takes place off-screen. The audience are given the pieces of this apparent about-turn, including his unrequited feelings for Lindsay, her urging that he give up drugs, and his general dissatisfaction with his own aimlessness. On first 
viewing, however, the sight of Nick taking part in a dance competition with his new girlfriend Sara is perhaps surprising to viewers. It is only on repeat viewing that the hints of Nick's shifting allegiances become somewhat clearer.

There are a number of reasons why audiences may elicit pleasure from repeat viewing, from gaining a sense of comfort to indulging a desire for nostalgia, or simply guaranteeing enjoyment. Klinger suggests that "[f]amiliarity enables viewers to experience both comfort and mastery", and this sense of mastery may be particularly important in understanding the appeal of repeat viewing of short-lived series. (2006: 154) In the absence of new episodes, attaining an in-depth knowledge of, and appreciation for, the few episodes that do exist may function as an additional source of pleasure. The narrative "foreknowledge" that Klinger identifies as a factor in repeated viewing of individual films holds weight here. (2006: 153) A mastery of Freaks and Geeks' narrative also allows for the discussion and pointing out of anachronisms, lists of which (since the official website was closed down) survive as IMDb trivia. Though such observations undermine the complete temporal authenticity of the programme, there is a particular pleasure for fans in this kind of activity. It takes time and dedication to discover that, for instance, Bill could not have been eating "I Can't Believe it's not Butter" in 1981, because the product was not yet available; such dedication signals a deeper connection to the show, reflecting the kind of audience activity commonly linked to cult programming. More broadly, this knowledge, accumulated through repeat viewings, may also allow fans to speculate more accurately about what might have happened to its characters had the series been permitted to continue, a narrative post-knowledge that may bring its own pleasures through discussion, interpretation and close examination of the text. 


\section{Conclusion}

In March 2016, Shout! released a Blu-Ray collectors' edition of Freaks and Geeks. In October 2016, the series was made available on the home streaming service Netflix in the UK. Although the series had previously been available on Amazon's rival Prime Video service, the move to Netflix heralded renewed reminders of the programme's critical promise. The Guardian, for example, highlighted the show's "delicate brilliance" and urged viewers to watch. (Raeside, 2016) Earlier in 2016, CBS listed it as one of the must-stream shows on Netflix US, where the show has been available, intermittently, since 2015 .

As a result, Freaks and Geeks' legacy now seems more assured than ever. From the foundations of cancellation and unavailability, its survival has been built on the back of fan action and commitment, and augmented by its revival across formats, from the original DVD release to the 2016 Blu-ray repackaging and the option to stream via Netflix. 1980 may be further away than ever, but Freaks and Geeks' perennial themes - insecurity, rebellion, fitting in-point to a universality that has allowed it to cultivate a new generation of viewers. Though its broadcast was short-lived, Shout!'s faith in this cult teen drama has ensured that fans can relive, again and again, exactly (as the show's tagline goes) "what high school was like for the rest of us". 


\section{Bibliography}

Abbott, S. (ed.) 2010. The Cult TV Book. London: I. B. Tauris.

Battis, J. 2010. “Trangressive TV”, in S. Abbott (ed.), The Cult TV Book. London: I. B. Tauris, pp.77-83.

Bierbaum, T. 1990. "Booming 80s behind it, vid faces uncertainty." Variety, Jan. 10, pp.31-2.

Davis, G. and K. Dickinson. (eds.) 2004. Teen TV: Genre, Consumption and Identity. London: BFI.

Dehnart, A. 2000. "Geek Love." Salon, Apr. 20. Available at: http://www.salon.com/2000/04/20/geeks_3/ [accessed Nov. 25, 2016]

Dickinson, K. 2004. “'My Generation': Popular Music, Age and Influence in Teen Drama of the 1990s", in Davis and Dickinson (eds.), Teen TV: Genre, Consumption and Identity. London: BFI, pp.99-111.

Gwenllian-Jones, S. and R. Pearson. 2004. Cult Television. Minneapolis: University of Minnesota Press.

Halfyard, J. K. 2010. "Boldly Going: Music and Cult TV", in S. Abbott (ed.), The Cult TV Book. London: I. B. Tauris, pp.121-128.

Hills, M. 2004. “Dawson's Creek: 'Quality Teen TV' and 'Mainstream Cult'?” in Davis and Dickinson (eds.), Teen TV: Genre, Consumption and Identity. London: BFI, pp.54-67. Jackson, J. 2009. “The 15 Best TV Shows That Were Cancelled Too Soon.” Paste Magazine, Oct. 13. Available at: https://www.pastemagazine.com/blogs/lists/2009/10/the-15-besttv-shows-that-were-canceled-too-soon.html [accessed Nov. 25, 2016]

Klinger, B. 2006. Beyond the Multiplex: Cinema, New Technologies, and the Home. Berkeley: University of California Press. 
Ornstein, S. 2015. "Motion Pictures: Competition, Distribution and Efficiencies", in V. Tremblay and C. Tremblay (eds.), Industry and Firm Studies. London: Routledge, pp.181-204.

Pearson, R. E. 2003. "Kings of Infinite Space: Cult Television Characters and Narrative Possibilities." Scope: An Online Journal of Film and Television Studies (Nov.) Available at: http://www.nottingham.ac.uk/scope/documents/2003/november-2003/pearson.pdf [accessed Oct. 17, 2016]

Raeside, J. 2016. "High School Antiheroes: Freaks and Geeks Finally Comes to Netflix." The Guardian, Oct. 7. Available at: https://www.theguardian.com/tv-andradio/tvandradioblog/2016/oct/07/freaks-and-geeks-netflix-judd-apatow-paul-feig [accessed Oct. 17, 2016]

Sheffield, R. 2016. "100 Greatest TV Shows of All Time.” Rolling Stone, Sep. 21. Available at: $\quad$ http://www.rollingstone.com/tv/lists/100-greatest-tv-shows-of-all-time-w439520 [accessed Nov. 25, 2016]

Time. 2007. "All-Time 100 TV Shows: Freaks and Geeks." Time, Sep. 6. Available at: http://time.com/collection-post/3101650/freaks-and-geeks/ [accessed Nov. 25, 2016]

Wee, V. 2004. "Selling Teen Culture: How American Multimedia Conglomeration Reshaped Teen Television in the 1990s", in Davis and Dickinson (eds.), Teen TV: Genre, Consumption and Identity. London: BFI, pp.87-98.

Wilcox, R. V. 2010. "The Aesthetics of Cult Television", in S. Abbott (ed.), The Cult TV Book. London: I. B. Tauris, pp. 31-39. 